Research paper

\title{
Geochemical application of tricyclic and tetracyclic terpanes biomarkers in crude oils of NW China
}

\author{
Shizhen Tao ${ }^{a}$, Chuanyuan Wang ${ }^{b,{ }^{*}}$, Jianguo Du ${ }^{c}$, Lei Liu ${ }^{c}$, Zhi Chen ${ }^{c}$ \\ ${ }^{a}$ Research Institute of Exploration and Development, China National Petroleum Corporation, Beijing 100083, China \\ ${ }^{\mathrm{b}}$ Yantai Institute of Coastal Zone Research, Chinese Academy of Sciences, Yantai 264003, China \\ c Institute of Earthguake Science, China Seismological Bureau, Beijing 100036, China
}

\section{A R T I C L E I N F O}

\section{Article history:}

Received 27 June 2014

Received in revised form

28 May 2015

Accepted 31 May 2015

Available online 6 June 2015

\section{Keywords:}

Crude oil

Source dependent parameters

Sedimentary organic facies

Tricyclic terpanes

Tetracyclic terpanes

\begin{abstract}
A B S T R A C T
Composition and distribution of tricyclic terpanes, tetracyclic terpanes and hopane in crude oils from Tarim, Turpan, Ordos and Qaidam basins, NW China, were investigated, and some new source dependent parameters were developed and evaluated. $C_{19}$ and $C_{20}$ tricyclic terpanes are more abundant in terrigenous oils, with $\mathrm{C}_{24}$ tetracyclic terpane dominant. Relatively higher carbon number tricyclic terpanes, especially $C_{23}$ tricyclic terpane, are often the dominant homologues in crude oils from saline lacustrine and marine sources. On the whole, the relative content of $\mathrm{C}_{23}$ tricyclic terpane of crude oils follow the order of saline lacustrine oils $>$ marine oils $>$ freshwater lacustrine oils $>$ terrigenous oils for $\mathrm{C}_{19-23}$ tricyclic terpane. Some new parameters based on the tricyclic/hopane and tetracyclic/tricyclic terpane as well as tetracyclic/hopane ratios, could be used to distinguish the oils and source rocks with similar maturity deposited in different sedimentary environments.
\end{abstract}

(c) 2015 Elsevier Ltd. All rights reserved.

\section{Introduction}

Tricyclic terpanes are important biomarkers and occur widely in source rock extracts and crude oils (de Grande et al., 1993; Fazeela et al., 2011). Tricyclic terpanes (TT) and tetracyclic terpanes (TeT) from sedimentary organic matter can provide valuable information to assess organic input, maturity, correlation of crude oils (Didyk et al., 1978; Azevedo et al., 1992; Farrimond et al., 1999; Tuo et al., 1999; Nady, 2008; Samuel et al., 2010; Wang et al., 2012; Zhang and Philp, 2012; Jin et al., 2014). The tricyclic terpane series are commonly observed in petroleum samples up to $C_{29}$, but the higher members of the series are often masked by hopanes in the $m / z 191$ mass chromatogram. In petroleum source rocks, an increase in the ratio of tricyclic terpanes relative to the hopanes as far as the late oil window has been observed and this is thought to reflect earlier thermal degradation of hopanes relative to the tricyclic terpanes (Farrimond et al., 1999). Peters and Moldowan (1993) suggested that $C_{19}$ or $C_{20}$ tricyclic terpanes are more abundant in terrigenous oils; while $\mathrm{C}_{23}$ tricyclic terpane is often the dominant homologue in crude oils with a marine source. Moreover, several tricyclic terpane maturity parameters are used to effectively assess the thermal

\footnotetext{
* Corresponding author.

E-mail address: cywang@yic.ac.cn (C. Wang).
}

maturities of carbonate source rocks, especially at the immature to early mature stages (Tuo et al., 1999). Although the origin of $C_{24} \mathrm{TeT}$ is still unknown, it is thought to originate from thermal or microbial degradation of hopanes (Peters et al., 2005). Farrimond et al. (1999) observed an increase in the $\mathrm{C}_{23}$ tricyclic terpanes maturity parameters $\mathrm{C}_{23} / \mathrm{C}_{21} \mathrm{TT}, \mathrm{C}_{23} / \mathrm{C}_{24} \mathrm{TT}$ and $\mathrm{C}_{23} / \mathrm{C}_{26} \mathrm{TT}$. Based on this, it can be concluded that the maturity of crude oil or source rocks might be difficult to assess in an oil-gas geochemistry study without careful examination of the type of organic constituents (e.g. marine/ freshwater algae or terrigenous land plant).

Although tricyclic and tetracyclic terpanes have been increasingly applied in petroleum exploration, limited studies were reported about the effect of depositional environments on the distribution of tricyclic and tetracyclic terpanes. The Tarim, Qaidam, Turpan and Ordos basins in NW China are important petroleum producing basins in China, which represent different depositional environments, such as marine, freshwater lacustrine, saline lacustrine and terrigenous environments. In this paper, some crude oil samples from Tarim, Qaidam, Turpan and Ordos basins were analyzed by gas chromatography-mass spectrometry (GC-MS) for the tricyclic and tetracyclic terpanes in order to help fill the knowledge gaps. To achieve the goal, the following tasks were carried out: (1) analyses of distribution of tricyclic and tetracyclic terpanes in crude oils from Tarim, Qaidam, Turpan and Ordos basins; (2) investigation of depositional environment effects on the 
distribution of tricyclic and tetracyclic terpanes; and (3) development of a set of source dependent parameters for oil correlation and differentiation.

\section{Geological background}

The Tarim, Qaidam, Turpan and Ordos basins in NW China are important petroleum producing basins in China. The Qaidam Basin, located in Qinghai Province, NW China, covers an area of $121,000 \mathrm{~km}^{2}$ and is a Mesozoic-Cenozoic sedimentary basin characterized by an inland saline lake facies. The Qaidam Basin has distinct petroleum systems, namely a Lower-Middle Jurassic freshwater lacustrine petroleum system in the northern margin, a Tertiary saline lacustrine oil system in the western part and Quaternary biogenic gas system in the eastern area (Zhang and Philp, 2012). The south area of western Qaidam Basin is the largest Tertiary saline lacustrine petroleum-producing area in China. The Turpan Basin, located in the Xinjiang Uygur Autonomous Region, NW China, covers an area of $53,500 \mathrm{~km}^{2}$ and is one of the three large sedimentary basins in Xinjiang Uygur Autonomous Region, NW China. The basin can be described as two depressions and one uplift in terms of its structural framework: the Turpan depression in the west, the Hami depression in the east and the Liaodun uplift in the middle. The Tarim Basin, located in the southern Xinjiang Uygur Autonomous Region, NW China, is one of the world's largest frontier basins, with an area of 560,000 $\mathrm{km}^{2}$. Tahe oilfield in Tarim Basin is the largest oilfield found in Paleozoic marine carbonate rocks in China, crude oils have been mainly recovered from the Ordovician carbonate. The Ordos Basin, a large intracontinental sedimentary basin in China with an area of about $37,104 \mathrm{~km}^{2}$, contains abundant Mesozoic crude oil resources with a reserve estimate of up to $10 \times 10^{8}$ metric tons of oil from Mesozoic reservoirs (Duan et al., 2008). The crude oils have been considered to be derived from non-marine source rocks. Details on the geology are available in Zhu et al. (2005), Duan et al. (2008), Yu et al. (2011), Zhang and Huang (2005), Zhang and Philp (2012) and Mo and Zhang (2012).

\section{Samples and experimental}

\subsection{Samples}

The crude oils from Tarim, Qaidam, Turpan and Ordos basins in NW China (Fig. 1) were separated into four kinds: marine oils,

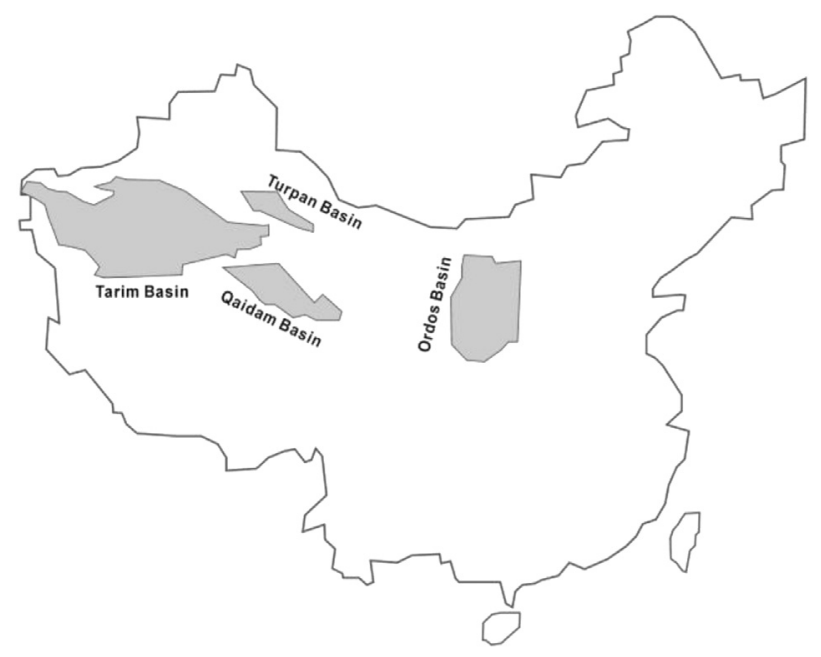

Fig. 1. Location map indicating the studied basins in China. freshwater lacustrine oils, saline lacustrine and terrigenous oils. A series of crude oils from Tarim Basin (TB-M) and (TB-SL), western Qaidam Basin (QB-SL), northern Qaidam Basin (QB-FL), Ordos Basin (OB-FL) and Turpan Basin (TUB-T) were collected and analyzed (Table 1). Ten crude oil samples were collected from Jiyuan oilfield in Ordos Basin. The samples are concentrated in Yanan Formation $\left(\mathrm{Y}_{7}, \mathrm{Y}_{8}, \mathrm{Y}_{9}\right)$ and Yanchang Formation $\left(\mathrm{C}_{1}, \mathrm{C}_{2}, \mathrm{C}_{4+5}, \mathrm{C}_{6}\right)$. Twelve oil samples collected from Gasicule oilfield in Qaidam Basin. Such samples are concentrated in $\mathrm{E}_{3}^{1}$ Formation and $\mathrm{N}_{1}-\mathrm{N}_{2}^{1}$ Formation. In addition, two crude oil samples in Lenghu 4 and 5 structures of Lenghu area from northern Qaidam Basin were also analyzed for comparison. The formation of the six crude oil samples collected from Tahe oilfield in Tarim Basin is $\mathrm{O}_{1-2} y$ Formation. There are two oil seepage collected from Ruoqiang area in southeastern Tarim Basin. There are two oil samples $\left(\mathrm{J}_{2} \mathrm{~s}, \mathrm{~J}_{2} \mathrm{q}\right)$ collected from Tuha oilfield in Turpan Basin.

\subsection{Experimental}

The oils were deasphaltened using hexane before fractionation and were separated into saturate hydrocarbons (Sat.), aromatic hydrocarbons (Aro.) and non-hydrocarbons (Non.) by column chromatography using $10 \mathrm{~g}$ of neutral alumina and $20 \mathrm{~g}$ of silica gel. Sat., Aro. and Non. were obtained by successively eluting with $n$ hexane, toluene and chloroform/methanol (98:2), respectively.

The saturated hydrocarbons were analyzed with a $6890 \mathrm{~N}$ GC5973N mass spectrometer. Sample extracts were injected in a splitless mode onto a HP-5 capillary column $(50 \mathrm{~m} \times 0.32$ $\mathrm{mm} \times 0.25 \mu \mathrm{m}$, Agilent Technologies, USA) at an initial temperature of $80{ }^{\circ} \mathrm{C}$. The GC oven temperature was programmed to $300{ }^{\circ} \mathrm{C}$ at $4{ }^{\circ} \mathrm{C} / \mathrm{min}$ and was held at the final temperature for $30 \mathrm{~min}$. Helium was used as a carrier gas. Mass spectrometer conditions were electron ionization at $70 \mathrm{eV}$ with an ion source temperature at $250{ }^{\circ} \mathrm{C}$.

The GC-MS system was operated in full scan mode. Individual $n$-alkanes were identified based on the retention time of the authentic standards ( $n-\mathrm{C}_{10-40}$, Sigma). The terpanes and steranes were detected in their key mass chromatograms $(m / z 191,217)$ based on the relative retention times and by comparing their mass spectra with published data. The standard deviation of the calculations of the peak areas was better than $0.5 \%$.

\section{Results and discussion}

\subsection{Source of organic matter and depositional environments of crude oils}

Pristane/phytane $(\mathrm{Pr} / \mathrm{Ph})$ ratios have been used to assess the redox potential of the depositional environment. It is generally accepted that very low values of the pristane/phytane ratio $(\leq 1)$ indicate anoxic conditions (Didky Zhang and Huang, 2005) while high values $(\mathrm{Pr} / \mathrm{Ph}>3)$ are related to terrigenous organic matter input under less restricted conditions (Peters et al., 2005; Duan et al., 2008). Gammacerane was first described in a study of the Green River shale in Colorado (Hills et al., 1966). The gammacerane precursor is tetrahymanol (XV) found in hypersaline palaeoenvironments in Green River shale (Henderson and Steel, 1971). More recently, gammacerane is commonly considered to be of tetrahymanol origin which occurs in saline waters (Fu and Sheng, 1989; Sinninghe Damsté et al., 1995; Yu et al., 2011).

The distribution of $\operatorname{Pr} / \mathrm{Ph}$ ratios and gammacerane index $\left(\mathrm{G} / \mathrm{C}_{30}\right.$ $\alpha \beta$ hopane) from crude oils in the Tarim, Qaidam, Ordos and Turpan basins show distinct differences (Fig. 2). The $\mathrm{Pr} / \mathrm{Ph}$ ratios of crude oils from Tarim Basin and Qaidam Basin are $<1$ indicating anoxic conditions whereas higher values $(1-3)$ of the crude oils from 
Table 1

Parameters of tricyclic terpane and tetracyclic terpane in crude oils.

\begin{tabular}{|c|c|c|c|c|c|c|}
\hline Samples numbers & $\mathrm{OB}-\mathrm{FL}$ & QB-SL & QB-FL & TB-M & TB-SL & TUB-T \\
\hline Oilfileds & Jiyuan & Gasicule & Lenghu & Tahe & Ruoqiang & Tuha \\
\hline Basin & Ordos & Qaidam & Qaidam & Tarim & Tarim & Turpan \\
\hline Sedimentary environment & Freshwater lacustrine & Saline lacustrine & Freshwater lacustrine & Marine & Saline lacustrine & Terrigenous \\
\hline$C_{31} 22 S /(22 S+22 R)$ & $0.58-0.60$ & $0.46-0.53$ & $0.56-0.57$ & $0.55-0.59$ & $0.52-0.53$ & $0.51-0.54$ \\
\hline$C_{29} 20 S /(20 S+20 R)$ & $0.50-0.56$ & $0.28-0.51$ & $0.51-0.55$ & $0.48-0.52$ & $0.39-0.42$ & $0.38-0.42$ \\
\hline CPI & $1.09-1.28$ & $0.90-0.98$ & $1.12-1.16$ & $0.97-1.09$ & $0.97-0.98$ & $1.12-1.19$ \\
\hline $\mathrm{C}_{19}+\mathrm{C}_{20} / \mathrm{C}_{23} \mathrm{TT}$ & $0.63-0.85$ & $0.46-0.62$ & $4.12-4.18$ & $0.31-0.40$ & $0.22-0.27$ & $1.95-1.86$ \\
\hline $\mathrm{C}_{19}+\mathrm{C}_{20}+\mathrm{C}_{21} / \mathrm{C}_{23}+\mathrm{C}_{24} \mathrm{TT}$ & $0.78-0.90$ & $0.67-0.86$ & $2.68-2.81$ & $0.41-0.51$ & $0.59-0.69$ & $1.79-1.87$ \\
\hline Tricyclic terpane index & $0.13-0.33$ & $1.31-1.64$ & $0.35-0.38$ & $2.32-2.88$ & $1.28-1.82$ & $0.08-0.10$ \\
\hline Tetracyclic terpane index & $0.02-0.04$ & $0.07-0.10$ & $0.06-0.08$ & $0.17-0.22$ & $0.12-0.14$ & $0.02-0.03$ \\
\hline $\mathrm{C}_{25} \mathrm{TT} / \mathrm{C}_{24} \mathrm{TeT}$ & $0.39-0.54$ & $1.28-1.72$ & $0.08-0.12$ & $1.02-1.38$ & $1.56-1.86$ & $0.13-0.15$ \\
\hline$\Sigma \mathrm{TTs} / \Sigma \mathrm{HOPs}$ & $0.41-1.50$ & $0.51-0.63$ & $0.66-0.86$ & $0.66-0.90$ & $0.35-0.37$ & $0.07-0.09$ \\
\hline Gammacerane indices & $0.02-0.04$ & $0.55-0.81$ & $0.02-0.03$ & $0.12-0.18$ & $0.46-0.48$ & $0.24-0.25$ \\
\hline $\mathrm{C}_{23} \mathrm{TT} / \mathrm{C}_{23} \mathrm{TT}+\mathrm{C}_{30} \mathrm{HOP}$ & $0.02-0.05$ & $0.19-0.31$ & $0.07-0.09$ & $0.37-0.4$ & $0.27-0.32$ & $0.02-0.03$ \\
\hline $\mathrm{C}_{24} \mathrm{TeT} / \mathrm{C}_{24} \mathrm{TeT}+\mathrm{C}_{26} \mathrm{TT}$ & $0.44-0.51$ & $0.27-0.33$ & $0.72-0.81$ & $0.38-0.46$ & $0.15-0.19$ & $0.72-0.74$ \\
\hline $\mathrm{C}_{24} \mathrm{TeT} / \mathrm{C}_{20-26} \mathrm{TT}$ & $0.16-0.21$ & $0.06-0.07$ & $0.30-0.40$ & $0.10-0.11$ & $0.08-0.12$ & $0.44-0.45$ \\
\hline $\mathrm{C}_{23} / \mathrm{C}_{21} \mathrm{TT}$ & $1.19-1.38$ & $1.28-1.67$ & $0.85-0.88$ & $2.38-2.94$ & $1.18-1.25$ & $1.48-1.57$ \\
\hline $\mathrm{C}_{25} / \mathrm{C}_{26} \mathrm{TT}$ & $0.38-0.45$ & $0.55-0.65$ & $0.31-0.33$ & $0.63-1.08$ & $0.29-0.36$ & $0.36-0.38$ \\
\hline $\mathrm{C}_{28} \mathrm{TT} / \mathrm{C}_{30} \mathrm{HOP}$ & $0.02-0.05$ & $0.19-0.29$ & $0.07-0.08$ & $0.25-0.28$ & $0.17-0.18$ & $0.01-0.02$ \\
\hline $\mathrm{C}_{29} \mathrm{TT} / \mathrm{C}_{30} \mathrm{HOP}$ & $0.02-0.05$ & $0.15-0.24$ & $0.06-0.08$ & $0.32-0.36$ & $0.15-0.16$ & $0.02-0.03$ \\
\hline
\end{tabular}

Note: $\mathrm{CPI}=1 / 2\left[\left(\mathrm{C}_{25}+\mathrm{C}_{27}+\mathrm{C}_{29}+\mathrm{C}_{31}+\mathrm{C}_{33}\right) /\left(\mathrm{C}_{24}+\mathrm{C}_{26}+\mathrm{C}_{28}+\mathrm{C}_{30}+\mathrm{C}_{32}\right)+\left(\mathrm{C}_{25}+\mathrm{C}_{27}+\mathrm{C}_{29}+\mathrm{C}_{31}+\mathrm{C}_{33}\right) /\left(\mathrm{C}_{26}+\mathrm{C}_{28}+\mathrm{C}_{30}+\mathrm{C}_{32}+\mathrm{C}_{34}\right)\right]$.

Ordos Basin and Turpan Basin suggest suboxic conditions. The oils in Qaidam Basin show the highest gammacerane index (0.55-0.79) and the lowest $\mathrm{Pr} / \mathrm{Ph}$ ratio $(0.48-0.66)$, indicating their source rocks were deposited under more anoxic, strongly reducing condition. In contrast, Turpan coal-derived oils and Lenghu oil from northern Qaidam have highest $\mathrm{Pr} / \mathrm{Ph}$ ratios, ranging from 1.56 to 1.98 , indicating that their source rocks were deposited under more oxic freshwater condition. The marine oils from Tarim Basin have relatively lower gammacerane indices $(0.12-0.48)$ and relatively lower $\mathrm{Pr} / \mathrm{Ph}$ ratios $(0.71-0.95)$, indicating their source rocks were also deposited in reducing, anoxic conditions, but less reductive compared to the Qaidam source rocks. The crude oils from Ordos Basin have lowest gammacerane indices $(0.02-0.04)$ and relatively higher $\mathrm{Pr} / \mathrm{Ph}$ ratios (1.20-1.71), indicating their source rocks were deposited in oxic and freshwater conditions.

The relative concentrations and distribution patterns of regular steranes are used as source parameters that can also differentiate depositional settings, based on studies of steranes in recent marine and terrigenous sediment (Peters et al., 2005; Nady, 2008). It is indicated that the oil (TB-M) from Tarim Basin are closely related to the Cambrian-Ordovician source rocks (Gu, 2000; Duan et al., 2009). For the oil (TB-SL), the upper Triassic-lower Jurassic in Minfeng-Ruoqiang depression of Tarim basin is the fluvial-

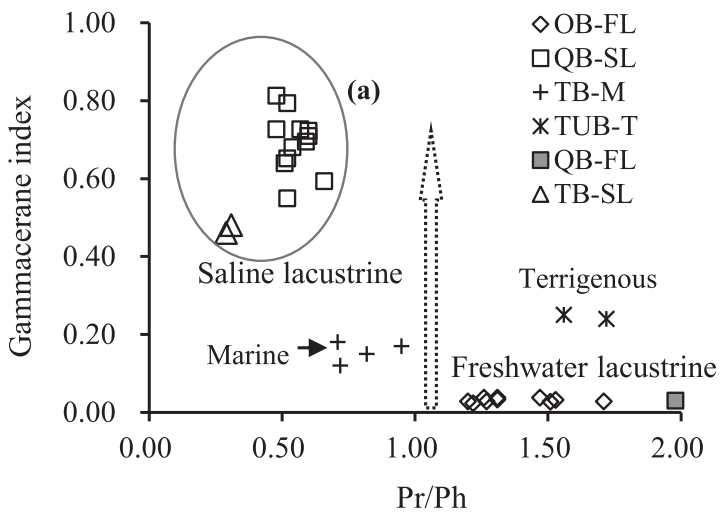

Fig. 2. Cross plot $\operatorname{Pr} / \mathrm{Ph}$ vs. $\mathrm{G} / \mathrm{C}_{30}$ HOP Note: HOP: $\mathrm{C}_{30} 17 \alpha(\mathrm{H}), 21 \beta(\mathrm{H})$-hopane. lacustrine facies limestones, clastic sedimentary rocks, with coal line and thin coal seam (You, 2005). The distribution patterns of the regular steranes $C_{27}, C_{28}$ and $C_{29}$ in oil samples can be divided into three types (Table 2). The contents of regular steranes $C_{27}-C_{28}-C_{29}$ of crude oils from Tarim Basin (TB-M), northern Qaidam (QB-FL) and Turpan Basin (TUB-T) follow the order of $C_{29}>>C_{27}>C_{28}$, suggesting a higher contribution of terrigenous higher plant to the organic source. In contrast, the contents of regular steranes $\mathrm{C}_{27}-\mathrm{C}_{28}-\mathrm{C}_{29}$ of crude oils in Qaidam Basin (QB-SL) and Tarim Basin (TB-SL) follow the order of $C_{27}>C_{29}>C_{28}$, with dominated algae organic input. The Ordos Basin is characterized by a predominance of steranes $C_{29}$, with the similar contents of $C_{27}$ and $C_{28}$. The results are consistent with the results of previous studies on the source of organic matter (Zhu et al., 2005; Duan et al., 2008; Yu et al., 2011; Zhang and Huang, 2012; Zhang and Philp, 2012; Mo and Zhang, 2012). $C_{31}$ - or $C_{32}$-homohopanes are used for calculations of the $22 \mathrm{~S} /(22 \mathrm{~S}+22 \mathrm{R})$ ratio. The $22 \mathrm{~S} /(22 \mathrm{~S}+22 \mathrm{R})$ ratio rises from 0 to about $0.6(0.57-0.62=$ equilibrium $)$ during maturation. Sediments with the maturity level equivalent to vitrinite reflectance $\left(R_{0}\right)=0.6 \%$ shows $22 \mathrm{~S} /(22 \mathrm{~S}+22 \mathrm{R})$ ratios in the range $0.5-0.54$ (Peters and Moldowan, 1993). In this study, the ratios of $22 \mathrm{~S} /(22 \mathrm{~S}+22 \mathrm{R})$ for $\mathrm{C}_{31} 17 \alpha(\mathrm{H}), 21 \beta(\mathrm{H})$-homohopanes range from 0.56 to 0.60 , indicating that all the crude oils have reached the thermal maturity within the "oil window".

\subsection{Distribution of tricyclic and tetracyclic terpanes in crude oils with different sedimentary environment}

In addition to hopanes, tricyclic and tetracyclic terpanes were also observed in $\mathrm{m} / \mathrm{z} 191$ mass chromatograms of the studied crude oils (Fig. 3). Aquino Neto et al. (1983) systematically investigated the distributions of tricyclic terpanes in oils and source rocks formed in a variety of depositional environments and showed that the $C_{23}$ member is often the dominant homologue in crude oils of a marine source while the $\mathrm{C}_{19}$ and $\mathrm{C}_{20}$ members are more abundant in terrestrial oils (Peters and Moldowan, 1993). High $C_{19} / C_{23}$ TT and $\mathrm{C}_{20} / \mathrm{C}_{23}$ TT ratios indicate important contribution from terrigenous organic matter (Hanson et al., 2000; Preston and Edwards, 2000; Volk et al., 2005). Specific parameters include $C_{23} / C_{21}$ (Ekweozor and Strausz, 1983), $C_{23} / C_{24}$ (Cassani et al., 1988) and $\left(C_{20}+C_{21}\right) /$ 
Table 2

Relative abundance of $\mathrm{C}_{27}-\mathrm{C}_{28}-\mathrm{C}_{29}$ Sterane.

\begin{tabular}{|c|c|c|c|c|c|c|}
\hline Samples & OB-FL & QB-SL & QB-FL & TB-M & TB-SL & TUB-T \\
\hline $\mathrm{C}_{27}$ Sterane & $26.94 \pm 0.81$ & $38.43 \pm 1.81$ & $24.04 \pm 2.15$ & $34.30 \pm 1.40$ & $41.25 \pm 2.06$ & $27.18 \pm 3.10$ \\
\hline $\mathrm{C}_{28}$ Sterane & $27.23 \pm 0.55$ & $26.26 \pm 1.81$ & $19.05 \pm 5.97$ & $14.47 \pm 1.45$ & $26.67 \pm 2.22$ & $19.74 \pm 2.40$ \\
\hline $\mathrm{C}_{29}$ Sterane & $45.83 \pm 0.74$ & $35.31 \pm 0.84$ & $56.91 \pm 6.04$ & $51.23 \pm 2.86$ & $32.08 \pm 2.18$ & $53.08 \pm 5.38$ \\
\hline
\end{tabular}

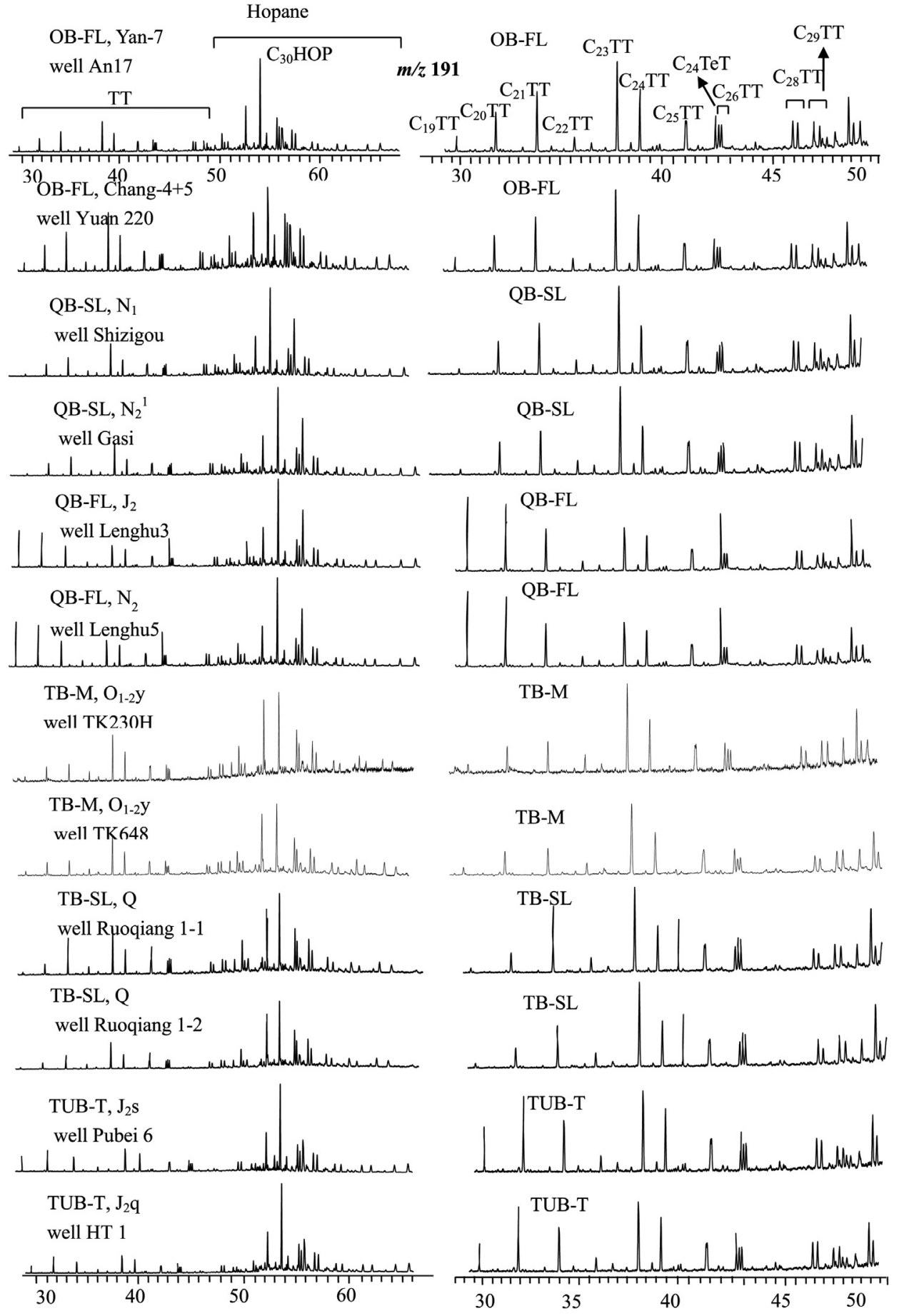

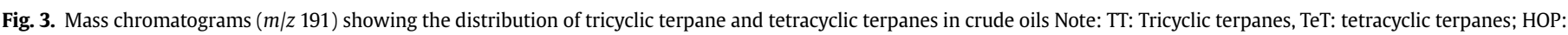
hopane. 
$\left(C_{23}+C_{24}\right)$ (Shi et al., 1988). The proportion of $C_{24}$ tetracyclic terpane relative to tricyclic terpanes may also be facies dependent. For example, high amounts of $\mathrm{C}_{24}$ tetracyclic terpane have been found in carbonate (Connan et al., 1986; Clark and Philp, 1989; Peters et al., 2008) and terrestrial (Philp and Gilbert, 1986; Hanson et al., 2000) samples. Therefore, the difference in the distributions of these tricyclic and tertacyclic terpanes can be used for oil family classification (Zhang and Huang, 2005). The carbon numbers of tricyclic terpanes range from $C_{19}$ to $C_{29}$, with $C_{23}$ as the peak except for oil samples from Turpan Basin. $C_{24}$ tetracyclic terpane was identified in all samples, and the $C_{23}$ tricyclic/ $C_{24}$ tetracyclic ratios range broadly from 0.45 to 4.96 . For the pentacyclic terpanes, carbon numbers vary between $C_{27}$ and $C_{35}$, with $C_{30}$ as the peak. $C_{23}-$ tricyclic terpane is the main peak in tricyclic terpanes, with $C_{24}, C_{21}$ or $\mathrm{C}_{20}$ being the second most dominant peak.

As indicated in Fig. 3, the distribution of tricyclic terpanes in oil samples from the Qaidam, Tarim, Ordos and Turpan basins can be divided into two patterns. The first one is observed in the oils from Qaidam (QB-SL), Tarim (TB-M, TB-SL) and Ordos basins (OB-FL), where the tricyclic trepans are characterized by a maximum at $C_{23}$. In contrast, the Turpan oil (TUB-T) and Qaidam (QB-FL) were characterized by a predominance of low carbon number tricyclic terpanes $\left(C_{19} C_{20}\right.$ and $\left.C_{21}\right)$. On the whole, $C_{19}$ or $C_{20}$ tricyclic terpane are more abundant in terrigenous oils; while relatively high carbon-number tricyclic terpanes, especially $C_{23}$ tricyclic terpane, are often the dominant homologue in crude oils of saline lacustrine and marine source (Fig. 4).

\subsection{Source dependent parameters based on the distribution tricyclic and tetracyclic terpanes}

The contents of tricyclic and tetracyclic terpanes in crude oils are closely related to the nature of their organic source (Seifert and Moldowan, 1978) and $C_{24}$ tetracyclic terpane $/\left(C_{24}\right.$ tetracyclic terpane $+\mathrm{C}_{26}$ tricyclic terpane) have been used to determine the oil-formation organic source. In the Tarim Basin, the marine and non-marine oils are distinguished according to the cross plot of $\mathrm{C}_{24}$ tetracyclic terpane $/\left(C_{24}\right.$ tetracyclic terpane $+C_{26}$ tricyclic terpane $)$ vs. $C_{23}$ tricyclic terpane $/\left(C_{23}\right.$ tricyclic terpane $+C_{30}$ hopane $)$ ratios (Hanson et al., 2000; Duan et al., 2008). Cross plots between several tricyclic terpane parameters and hopane parameters have been described and the values of the parameters are provided in Table 1 and Fig. 5. In this study, terrigenous oils, freshwater lacustrine oils, saline lacustrine and marine oils are well distinguished according to this cross plot (Fig. 5a). Previous data have indicated that in general, $C_{25} / C_{26}$ tricyclic terpane $\left(C_{25} / C_{26} T T\right)$ and $C_{25}$ tricyclic terpane/ $C_{24}$ tetracyclic terpane $\left(C_{25} \mathrm{TT} / \mathrm{C}_{24} \mathrm{TeT}\right)$ ratios $>1$ were associated with marine oils, whereas the values $<1$ inferred non-

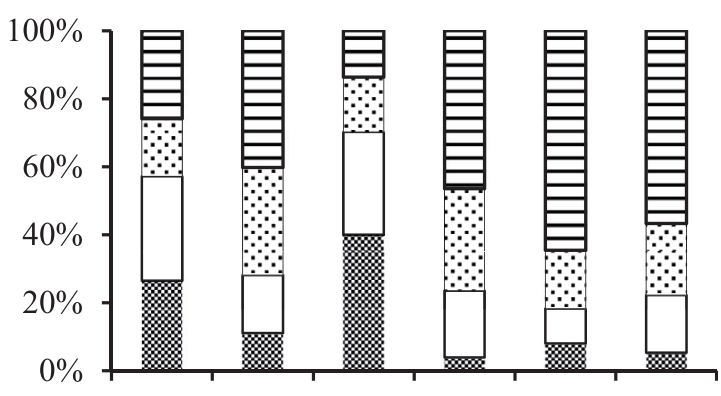

TUB-T OB-FL QB-FL QB-SL TB-SL TB-M

\section{口C23TT $₫ \mathrm{C} 21 \mathrm{TT} \square \mathrm{C} 20 \mathrm{TT} \approx \mathrm{C} 19 \mathrm{TT}$}

Fig. 4. Relative composition of $\mathrm{C}_{19} \mathrm{TT}, \mathrm{C}_{20} \mathrm{TT}, \mathrm{C}_{21} \mathrm{TT}$ and $\mathrm{C}_{23} \mathrm{TT}$ in different crude oils. marine oils (Burwood et al., 1992; Hanson et al., 2000). It can be shown that the terrigenous oils, freshwater lacustrine oils, saline lacustrine and marine oils are well distinguished according to the cross plot of $\mathrm{C}_{25} / \mathrm{C}_{26} \mathrm{TT}$ vs. $\mathrm{C}_{25} \mathrm{TT} / \mathrm{C}_{24} \mathrm{TeT}$ ratios (Fig. $5 \mathrm{~b}$ ). $\mathrm{C}_{25} / \mathrm{C}_{26} \mathrm{TT}$ and $\mathrm{C}_{25} \mathrm{TT} / \mathrm{C}_{24} \mathrm{TeT}$ ratios $<1$ were associated with terrigenous oils, saline lacustrine and freshwater lacustrine oils.

The ratio of $\mathrm{C}_{24}$ tetracyclic terpane to the sum of the $\mathrm{C}_{20-26}$ tricyclic terpanes $\left(\mathrm{C}_{24} \mathrm{TeT} / \mathrm{C}_{20}-26 \mathrm{TT}\right)$ increases towards the oil window and then decreases again within the oil window (Farrimond et al., 1999). This behavior is the result of an initially greater rate of generation of the tetracyclic compound compared with the tricyclics, followed by more rapid thermal degradation in the later part of the oil window. Farrimond et al. (1999) also found that the $C_{24}$ tetracyclic terpane $/ C_{30} \alpha \beta$ hopane ratio $\left(C_{24} \mathrm{TeT} /\right.$ $\mathrm{C}_{30} \mathrm{HOP}$ ) shows a marked increase during the last part of the oil window. The proportion of $\mathrm{C}_{24}$ tetracyclic terpane relative to tricyclic terpanes or hopanes may also be facies dependent. For example, high amounts of $\mathrm{C}_{24}$ tetracyclic terpane have been found in terrigenous samples (Fig. 3). In this study, the crude oils from terrigenous source rocks in Turpan Basin have higher $\mathrm{C}_{24} \mathrm{TeT} /$ $\mathrm{C}_{20-26} \mathrm{TT}$ (Fig. 5e).

The tricyclic and tetracyclic terpane are slightly more resistant to biodegradation and thermal degradation than isoprenoid alkanes even hopane (Peters et al., 2005). A plot of the selected tricyclic and tertacyclic terpane ratios reveals distinct difference among the oils, indicating difference in source character, even though a maturity influence cannot be ruled out (Farrimond et al. 1999). Some new source dependent parameters based on the distribution tricyclic and tetracyclic terpanes were also developed. It is worthwhile to mention that, the cross plots of $\mathrm{C}_{25}$ tricyclic terpanes $/ C_{24}$ tetracyclic terpane vs. $C_{25} / C_{26}$ tricyclic terpanes (Fig. $5 b$ ), $\left(\mathrm{C}_{19}+\mathrm{C}_{20}+\mathrm{C}_{21}\right) /\left(\mathrm{C}_{23}+\mathrm{C}_{24}\right)$ tricyclic terpanes vs. $\Sigma \mathrm{TTs} / \Sigma \mathrm{HOPs}$ is (Fig. 5c), $C_{23} / C_{21}$ tricyclic terpane vs. $\left(C_{19}+C_{20}\right) / C_{23}$ tricyclic terpanes (Fig. 5d), can be well used to determine the oil-formation organic source. However, the cross plot of $\mathrm{C}_{23} / \mathrm{C}_{21}$ tricyclic terpane vs. $\left(C_{19}+C_{20}\right) / C_{23}$ tricyclic terpanes (Fig. $5 d$ ) can not always distinguish the freshwater lacustrine oils from saline lacustrine oils. $\mathrm{C}_{23}$ TT seems to be indicative of carbonate settings in marine source rocks and oils (Peters and Moldowan, 1993). Thus, $\mathrm{C}_{23} \mathrm{TT} /$ $\left(C_{23} \mathrm{TT}+\mathrm{C}_{30} \mathrm{HOP}\right)$ and $\mathrm{C}_{23} \mathrm{TT} / \mathrm{C}_{21}$ TT is higher for T-M oils, which agree well with the Fig. $5 \mathrm{a}$. The result supports the effectiveness of these parameters as indicators of crude oil genesis. Diagnostic ratios vary greatly between oils from different regions. There is also a large scatter in this set of oils in these cross-plot data. This implies that such ratios may be used to discriminate different oils. It is worth to notice that the source of organic matter (terrigenous higher plant/algae input) have little effect on such parameters derived from tricyclic and tetracyclic terpanes. As a result, such maturity parameters involving the $C_{24}$ tetracyclic terpane is not only useful maturity parameter but also the source dependent parameters, which are most appropriate where organic facies are similar.

\subsection{Tricyclics/hopanes ratio}

The distribution and abundance of peaks $\mathrm{C}_{28}$ and $\mathrm{C}_{29}$ tricyclic terpanes in the oil samples reveals an interesting relationship among oil samples with different depositional environment. The tricyclics/(tricyclics + hopanes) parameter shows a dramatic increase within the latter part of the oil window, due to the greater relative thermal stability of the tricyclic terpanes (Farrimond et al., 1999). It is noticed that a good correlation is seen between the proportion of $\mathrm{C}_{23} \mathrm{TT} / \mathrm{C}_{30} \mathrm{TT}$ and $\mathrm{C}_{24} \mathrm{TeT} / \mathrm{C}_{30}$ (Fig. $6 \mathrm{a}$ ), $\mathrm{C}_{28} \mathrm{TT} / \mathrm{C}_{30} \mathrm{TT}$ and $\mathrm{C}_{28} \mathrm{TT} / \mathrm{C}_{30}$ (Fig. 6b). The relationship is systematic in a linear manner $\left(R^{2}=0.83,0.84\right.$, respectively) and it appears to be source specific. 

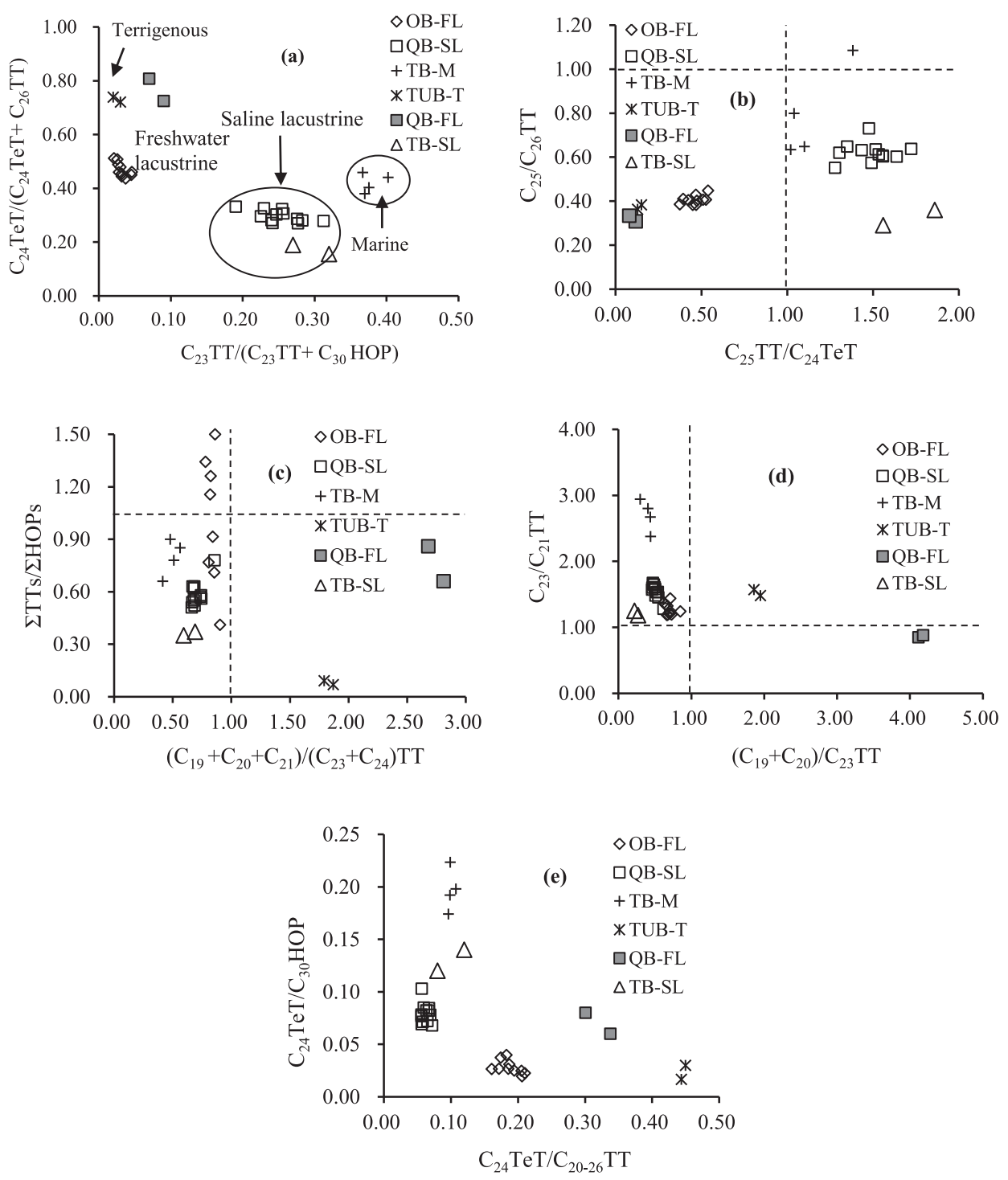

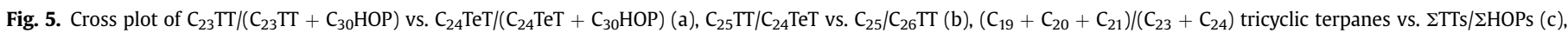
$\mathrm{C}_{19}+\mathrm{C}_{20} \mathrm{TT} / \mathrm{C}_{23} \mathrm{TT}$ vs. $\mathrm{C}_{23} / \mathrm{C}_{21} \mathrm{TT}(\mathrm{d}), \mathrm{C}_{24} \mathrm{TeT} / \mathrm{C}_{20-26} \mathrm{TT}$ vs. $\mathrm{C}_{24} \mathrm{TeT} / \mathrm{C}_{30} \mathrm{HOP}(\mathrm{e})$. Note: TTs/HOPs: $\mathrm{C}_{19}$ to $\mathrm{C}_{29}$ (excluding $\mathrm{C}_{22}$ and $\mathrm{C}_{27}$ ) tricyclic terpanes/ $\mathrm{C}_{29}-\mathrm{C}_{35}$ hopanes.

The tricyclic terpane index and tetracyclic terpane index (Hegazi and El-Gayar, 1999) follow the similar trends (Fig. 6c). It reflects changes in the source organic facies (marine, saline lacustrine). However, these parameters do not distinguish terrigenous and freshwater lacustrine oils. As a result, the tricyclics/hopanes parameter is not only useful maturity parameter but also the source dependent parameters. Consequently, such maturity parameters involving the tricyclic terpane are most appropriate where organic facies are similar.

\section{Conclusions}

The tricyclic terpane in freshwater lacustrine oils, saline lacustrine oils and marine oils are dominated by relative high-carbon number tricyclic terpanes, with $\mathrm{C}_{23}$ as a dominated peak. On the whole, $\mathrm{C}_{19}$ or $\mathrm{C}_{20}$ tricyclic terpane are more abundant in terrigenous oils (TUB-T, Turpan Basin) or freshwater lacustrine oils (QB-FL, northern Qaidam Basin); while relatively high carbon-number tricyclic terpanes, especially $C_{23}$ tricyclic terpane, are often the dominant homologue in crude oils of saline lacustrine (QB-SL, Qaidam; TB-SL, Southeastern Tarim) and marine source (TB-M, Tarim Basin). The cross plots of $\mathrm{C}_{24} \mathrm{TeT} /\left(\mathrm{C}_{24} \mathrm{TeT}+\mathrm{C}_{26} \mathrm{TT}\right)$ vs. $\mathrm{C}_{23} \mathrm{TT} /$ $\left(\mathrm{C}_{23} \mathrm{TT}+\mathrm{C}_{30} \mathrm{HOP}\right), \mathrm{C}_{25} \mathrm{TT} / \mathrm{C}_{24} \mathrm{TeT}$ vs. $\mathrm{C}_{25} \mathrm{TT} / \mathrm{C}_{26} \mathrm{TT},\left(\mathrm{C}_{19}+\mathrm{C}_{20}+\mathrm{C}_{21}\right) /$ $\left(\mathrm{C}_{23}+\mathrm{C}_{24}\right)$ TT vs. $\Sigma \mathrm{TT} / \Sigma$ HOPs, $\mathrm{C}_{23} / \mathrm{C}_{21}$ TT vs. $\left(\mathrm{C}_{19}+\mathrm{C}_{20}\right) / \mathrm{C}_{23} \mathrm{TT}$, $\mathrm{C}_{24} \mathrm{TeT} / \mathrm{C}_{20-26} \mathrm{TT}$ vs. $\mathrm{C}_{24} \mathrm{TeT} / \mathrm{C}_{30} \mathrm{HOP}$, can well be used to determine the oil-formation organic source. Furthermore, the cross plots of $\mathrm{C}_{23} \mathrm{TT} / \mathrm{C}_{30} \mathrm{HOP}$ vs. $\mathrm{C}_{24} \mathrm{TeT} / \mathrm{C}_{30} \mathrm{HOP}, \mathrm{C}_{28} \mathrm{TT} / \mathrm{C}_{30} \mathrm{HOP}$ vs. $\mathrm{C}_{29} \mathrm{TT} / \mathrm{C}_{30} \mathrm{HOP}$, TrTI vs. TeTI, could also be used to distinguish the crude oils with different sedimentary environments, which are most appropriate where the maturity of them are similar. The relationship for the latter two cross plots are all systematic in a linear manner $\left(\mathrm{R}^{2}=0.89,0.84\right.$, respectively) and it appears to be source specific. However, such parameters can not distinguish the terrigenous oils from freshwater lacustrine oils. There is little relation between the source of organic matter (terrigenous higher plant/algae input) and the parameters derived from tricyclic and tetracyclic terpanes. 

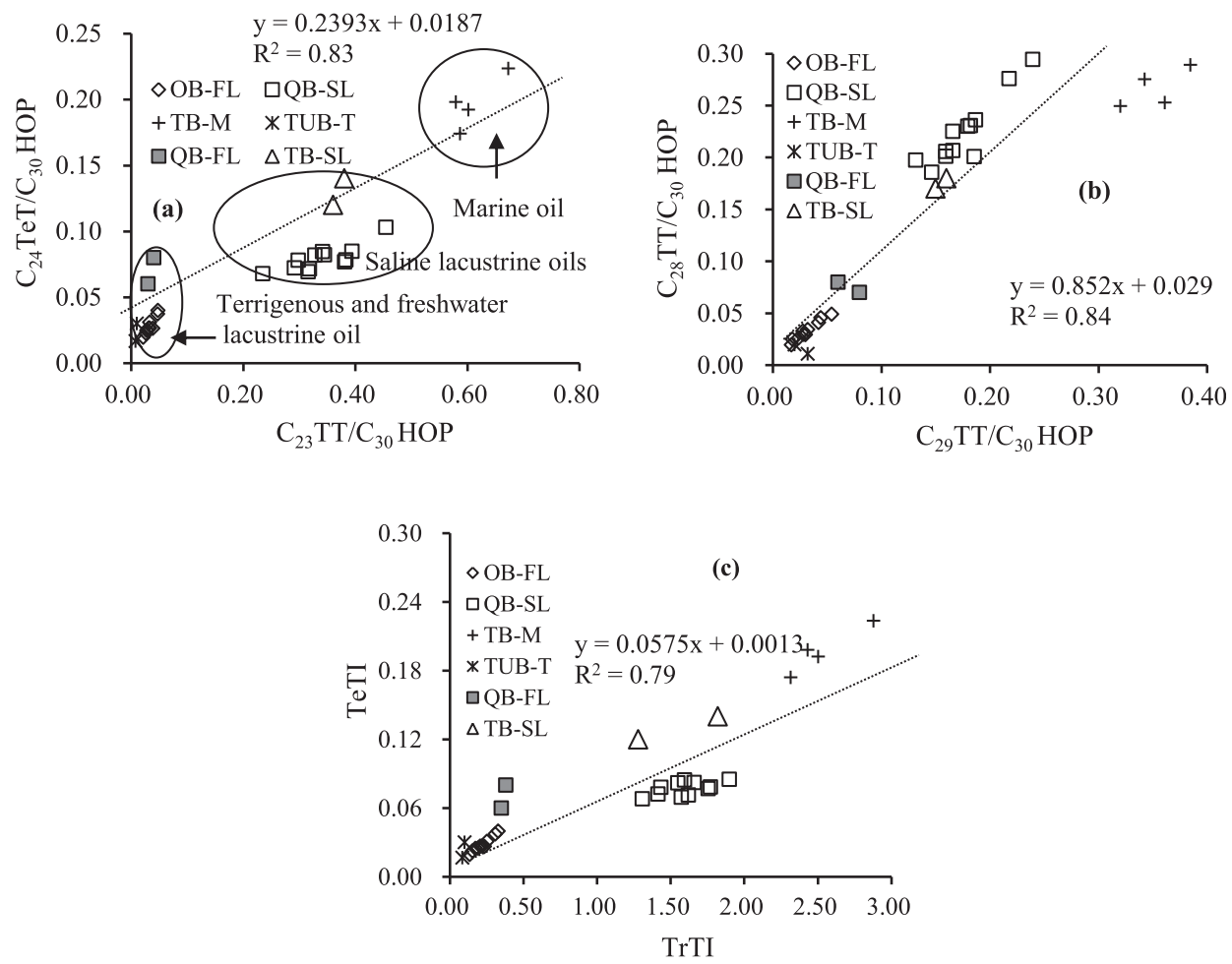

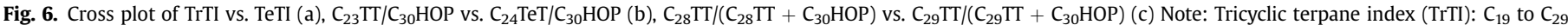
(excluding $\mathrm{C}_{22}$ and $\mathrm{C}_{27}$ ) tricyclic terpanes $/ \mathrm{C}_{30} 17 \alpha(\mathrm{H}), 21 \beta(\mathrm{H})$-hopane; Tetracyclic terpane index (TeTI): $\mathrm{C}_{24}$ Tetracyclic terpane/C $\mathrm{C}_{30} 17 \alpha(\mathrm{H}), 21 \beta(\mathrm{H})$-hopane.

\section{Acknowledgments}

This work was financially supported by the Major Program of the Ministry of Finance and the state (2011ZX05001-001), Project of on-site sediment microbial remediation of public area of central Bohai Sea, North China Sea Branch of State Oceanic Administration (QDZC20150420-002), Key Projects in the Yantai Science \& Technology Pillar Program (2011060) and National Natural Science Foundation of China (Grant No. 40806048). Special thanks are given to the editors and reviewers for their useful suggestions and comments.

\section{References}

Aquino Neto, F.R., Trendel, J.M., Restle, A., Connan, J., Albrecht, P.A., 1983. Occurrence and formation of tricyclic and tetracyclic terpanes in sediments and petroleums. In: Bjorøy, M., et al. (Eds.), Advances in Organic Geochemistry 1981. John Wiley and Sons, pp. 659-667.

Azevedo, D.A., Aquino Neto, F.R., Simoneit, B.R.T., Pinto, A.C., 1992. Novel series of tricyclic aromatic terpanes characterized in Tasmanian tasmanite. Org. Geochem. 18, 9-16.

Burwood, R., Leplat, P., Mycke, B., Paulet, J., 1992. Rifted margin source rock deposition: a carbon isotope and biomarker study of a West African lower cretaceous "Lacustrine" section. Org. Geochem. 19, 41-52.

Cassani, F., Gallango, O., Talukdar, S., Vallejos, C., Ehrmann, U., 1988. Methylphenanthrene maturity index of marine source rock extracts and crude oils from the Maracaibo Basin. Org. Geochem. 13, 73-80.

Clark, J.P., Philp, R.P., 1989. Geochemical characterization of evaporite and carbonate depositional environments and correlation of associated crude oils in the Black Creek basin, Alberta. Can. Pet. Geol. Bull. 37, 401-416.

Connan, J., Bouroullec, J., Dessort, D., Albrecht, P., 1986. The microbial input in carbonate-anhydrite facies of a sabkha palaeoenvironment from Guatemala: a molecular approach. Org. Geochem. 10, 29-50.

de Grande, S.M.B., Aquino Neto, F.R., Mello, M.R., 1993. Extended tricyclic terpanes in sediments and petroleum. Org. Geochem. 20, 1039-1047.

Didyk, B.M., Simoneit, B.R.T., Brassell, S.C., Eglinton, G., 1978. Organic geochemical indicators of palaeoenvironmental conditions of sedimentation. Nature 272, 216-222.
Duan, Y., Wang, C.Y., Zheng, C.Y., Wu, B.X., Zheng, G.D., 2008. Geochemical study of crude oils from Xifeng oilfield of Ordos Basin, China. J. Asian Earth Sci. 31 $341-356$.

Duan, Y., Yu, W.X., Zheng, Z.Y., Wang, C.Y., Wu, B.X., Sun, T., 2009. Study of oil-source correlation for Tahe Oilfield of Tarim Basin. Acta Sedimentol. Sin. 27, 164-171.

Ekweozor, C.M., Strausz, O.P., 1983. Tricyclic terpanes in the Athabasca oil sands their geochemistry. In: Bjorøy, M., et al. (Eds.), Advances in Organic Geochemistry 1981. John Wiley and Sons, pp. 746-766.

Farrimond, P., Bevan, C.J., Bishop, A.N., 1999. Tricyclic terpane maturity parameters response to heating by an igneous intrusion. Org. Geochem. 30, 1011-1019.

Fazeela, T., Asif, M., Jalees, M.I., Saleem, A., Nazir, A., Saleem, H., Nasir, S., Nadeem, S. 2011. Source correlation between biodegraded oil seeps and a commercial crude oil from the Punjab Basin, Pakistan. J. Petrol. Sci. Eng. 77, 1-9.

Fu, J.M., Sheng, G.Y., 1989. Biological marker composition of typical source rocks and related oils of terrigenous origin in the People's Republic of China: a review. Appl. Geochem. 4, 13-22.

$\mathrm{Gu}$, Y., 2000. Forming mechanism of hydrocarbon pools in Tahe oilfield of the northern Tarim basin. Exp. Pet. Geol. 22, 308-312 (in Chinese)

Hanson, A.D., Zhang, S.C., Moldowan, J.M., Liang, D.G., Zhang, B.M., 2000. Molecular organic geochemistry of the Tarim basin. Northwest China Am. Assoc. Pet. Geol. Bull. 84, 1109-1128.

Hegazi, A.H., El-Gayar, M.Sh, 1999. Geochemical characterization of a biodegraded crude oil, Assran field, Central Gulf of Suez. J. Petrol. Geol. 32, 343-355.

Henderson, W., Steel, G., 1971. Isolation and characterization of a triterpenoid alcohol from Green River Shale. J. Chem. Soc. Chem. Commun. 21, 1331-1332.

Hills, I.R., Whitehead, E.V., Anders, D.E., Cummins, J.J., Robinson, W.E., 1966. An optically active triterpane, gammacerane, in Green River, Colorado, oil shale bitumen. J. Chem. Soc. Chem. Commun. 20, 752-754.

Jin, X.D., Pan, C.C., Yu, S., Li, E., Wang, J., Fu, X.D., Oin, J.Z., Xie, Z.Y., Zheng, P., Wang, L.S., Chen, J.P., Tan, Y.M., 2014. Organic geochemistry of marine source rocks and pyrobitumencontaining reservoir rocks of the Sichuan Basin and neighbouring areas, SW China. Mar. Pet. Geol. 56, 147-165.

Mo, X.Y., Zhang, M., 2012. Geochemical characteristics of aromatic hydrocarbons in saline lacustrine crude oils and their significance as exemplified by the south area of western Qaidam Basin. Chin. J. Geochem. 31, 476-484.

Nady, M. M. El, 2008. Biomarkers assessment of crude oils and extracts from Jurassic-cretaceous rocks, North Qattara depression, North western Desert. Egypt. Petrol. Sci. Technol. 26, 1063-1082.

Peters, K.E., Moldowan, J.M., 1993. Interpreting Molecular Fossils in Petroleum and Ancient Sediments. The Biomarker Guide. Prentice Hall, Englewood Cliffs, N.J.

Peters, K.E., Walters, C.C., Moldowan, J.M., 2005. The Biomarker Guide, second ed. vol. 2. Cambridge University Press, Cambridge.

Peters, K.E., Hostettler, F.D., Lorenson, T.D., Rosenbauer, R.J., 2008. Families of Miocene Monterey crude oil, seep, and tarball samples, coastal California. AAPG Bull. 92, 1131-1152. 
Philp, R.P., Gilbert, T.D., 1986. Biomarker distributions in Australian oils predominantly derived from terrigenous source material. Org. Geochem. 10, 73-84.

Preston, J.C., Edwards, D.S., 2000. The petroleum geochemistry of oils and source rocks from the northern Bonaparte Basin, offshore northern Australia. APEA J. 40, 257-282.

Samuel, O.J., Kildahl-Andersen, G., Nytoft, H.P., Johansen, J.E., Jones, M., 2010. Novel tricyclic and tetracyclic terpanes in Tertiary deltaic oils: structural identification, origin and application to petroleum correlation. Org. Geochem. 41, 1326-1337.

Seifert, W.K., Moldowan, J.M., 1978. Application of steranes, terpanes and monoaromatics to the maturation, migration and source of crude oils. Geochim. Cosmochim. Acta 42, 77-95.

Shi, J., Wang, B., Zhang, L., Hong, Z., 1988. Study on diagenesis of organic matter in immature rocks. Org. Geochem. 13, 869-874.

Sinninghe Damsté, J.S., Kenig, F., Koopmans, M.P., Köster, J., Schouten, S., Hayes, J.M., de Leeuw, J.W., 1995. Evidence for gammacerane as an indicator of watercolumn stratification. Geochim. Cosmochim. Acta 59, 1895-1900.

Tuo, J.,C., Wang, X.B., Chen, J.F., 1999. Distribution and evolution of tricyclic terpanes in lacustrine carbonates. Org. Geochem. 30, 1429-1435.

Volk, H., George, C.S., Middleton, H., Schofield, S., 2005. Geochemical comparison of fluid inclusion and present-day oil accumulations in the Papuan Foreland evidence for previously unrecognised petroleum source rocks. Org. Geochem. 36, 29-51.

Wang, C.Y., Du, J.G., Wang, W.C., 2012. Distribution and isomerization of terpanes in pyrolyzates of lignite at high pressures and temperatures. J. Petrol. Geol. 35, 377-388.

You, D.H., 2005. Depositional environment of original organic matter of oil show in Ruoqiang area, southeastern fault-uplift of the Tarim basin. West China Pet. Geosci. 1, 170-1889 (in Chinese).

Yu, Q.H., Wen, ZJ. Tang, YJ., 2011. Geochemical characteristics of Ordovician crude oils in the northwest of the Tahe oil field, Tarim Basin. Chin. J. Geochem. 30, 93-98.

Zhang, S.C., Huang, H.P., 2005. Geochemistry of Palaeozoic marine petroleum from the Tarim Basin, NW China: Part 1. Oil family classification. Org. Geochem. 36, 1204-1214.

Zhang, M., Philp, P., 2012. Geochemical characteristics of saturate hydrocarbons in crude oils and source rocks of the Qaidam, Tarim, Turpan basins, NW China. Chin. J. Geochem. 31, 264-275.

Zhu, Y.M., Weng, H.X., Su, A.G., Liang, D.G., Peng, D.H., 2005. Geochemical characteristics of Tertiary saline lacustrine oils in the Western Qaidam Basin. Northwest China Appl. Geochem. 20, 1875-1889. 